\title{
Regulation of anaerobic methane oxidation in sediments of the Black Sea
}

\author{
N. J. Knab ${ }^{1,2}$, B. A. Cragg ${ }^{3}$, E. R. C. Hornibrook ${ }^{4}$, L. Holmkvist ${ }^{1}$, R. D. Pancost ${ }^{4}$, C. Borowski ${ }^{1}$, R. J. Parkes ${ }^{3}$, and \\ B. B. Jørgensen ${ }^{1,5}$ \\ ${ }^{1}$ Max-Planck Institute for Marine Microbiology, Department of Biogeochemistry, Celsiusstr. 1, 28359 Bremen, Germany \\ ${ }^{2}$ University of Southern California, 3616 Trousdale Parkway, AHF107, Los Angeles CA 90089, USA \\ ${ }^{3}$ School of Earth and Oceans Sciences, Cardiff University, Main Building, Park Place, Cardiff, Wales, CF103YE, UK \\ ${ }^{4}$ Bristol Biogeochemistry Research Centre, Department of Earth Sciences, University of Bristol, Wills Memorial Building, \\ Queens Road, Bristol, England, BS8 1RJ, UK \\ ${ }^{5}$ Center for Geomicrobiology, Department of Biological Sciences, Aarhus University, Ny Munkegade, Bld. 1535, \\ 8000 Aarhus C, Denmark
}

Received: 7 April 2008 - Published in Biogeosciences Discuss.: 30 May 2008

Revised: 16 July 2009 - Accepted: 28 July 2009 - Published: 7 August 2009

\begin{abstract}
Anaerobic oxidation of methane (AOM) and sulfate reduction (SRR) were investigated in sediments of the western Black Sea, where upward methane transport is controlled by diffusion. To understand the regulation and dynamics of methane production and oxidation in the Black Sea, rates of methanogenesis, AOM, and SRR were determined using radiotracers in combination with pore water chemistry and stable isotopes. In the Danube Canyon and the Dnjepr palaeo-delta AOM did not consume methane effectively and upwards diffusing methane created an extended sulfate-methane transition zone (SMTZ) that spread over more than $2.5 \mathrm{~m}$ and was located in brackish and limnic sediment. Measurable AOM rates occurred mainly in the lower part of the SMTZ, sometimes even at depths where sulfate seemed to be unavailable. The inefficiency of methane oxidation appears to be linked to the paleoceanographic history of the sediment, since in all cores methane was completely oxidized at the transition from the formerly oxic brackish clays to marine anoxic sediments. The upward tailing of methane was less pronounced in a core from the deep sea in the area of the Dnjepr Canyon, the only station with a SMTZ close to the marine deposits. Sub-surface sulfate reduction rates were mostly extremely low, and in the SMTZ were even lower than AOM rates. Rates of bicarbonate-based methanogenesis were below detection limit in two of the cores, but $\delta^{13} \mathrm{C}$ values of methane indicate a biogenic origin. The most $\delta^{13} \mathrm{C}$ -
\end{abstract}

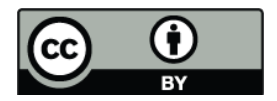

Correspondence to: N. J. Knab (knab@usc.edu) depleted isotopic signal of methane was found in the SMTZ of the core from the deep sea, most likely as a result of carbon recycling between AOM and methanogenesis.

\section{Introduction}

The process of anaerobic oxidation of methane (AOM) is widespread in continental margin sediments and occurs in a variety of different environments, including diffusion controlled sediments (Iversen and Jørgensen, 1985), sediments containing shallow gas accumulations (Niemann et al., 2005; Treude et al., 2005b), gas-hydrate bearing sediments (Treude et al., 2003; Joye et al., 2004; Orcutt et al., 2004), and mud volcanoes (Niemann et al., 2006), In the western part of the Black Sea, which is dominated by an extensive shelf in the northwest and by river deltas of the Danube and Dnjepr rivers, the sediment contains large amounts of methane, and numerous active methane seeps (Popescu et al., 2001). These seeps are mainly located above the gas hydrate stability zone, at the transition from the continental shelf to the upper slope, and are common in the area of the Danube canyon and the Dnjepr paleo-delta (Naudts et al., 2006). A unique feature of methane seeps in the anoxic part of the Black Sea are carbonate chimneys that grow from the sediment up into the water column and which are overgrown by thick bacterial mats mediating AOM (Michaelis et al., 2002; Treude et al., 2005a).

The stratified sediments of the Black Sea consist of limnic and brackish clay that was deposited before $7500 \mathrm{yr}$ BP and represent the oxic period of the Black Sea. After the intrusion

Published by Copernicus Publications on behalf of the European Geosciences Union. 
Table 1. Characteristics of the three sites and the gravity cores studied.

\begin{tabular}{llllllll}
\hline Core ID & Location & $\begin{array}{l}\text { Latitude } \\
\text { [Deg./Min] }\end{array}$ & $\begin{array}{l}\text { Longitude } \\
\text { [Deg./Min] }\end{array}$ & $\begin{array}{l}\text { Water depth } \\
{[\mathrm{m}]}\end{array}$ & $\begin{array}{l}\text { Unit IIb-IIa } \\
\text { transition }\end{array}$ & $\begin{array}{l}\text { Depth of } \\
\mathrm{pCH}_{4}>1 \text { bar }\end{array}$ & $\begin{array}{l}\text { Depth of } \\
\text { blackbands }\end{array}$ \\
\hline P771GC & Paleo-Danube & $43^{\circ} 37.83^{\prime}$ & $30^{\circ} 09.69^{\prime}$ & 683 & $\sim 70 \mathrm{~cm}$ & $400 \mathrm{~cm}$ & - \\
P806GC & Paleo-Dnjepr & $44^{\circ} 46.83^{\prime}$ & $3159.30^{\prime}$ & 205 & $\sim 10 \mathrm{~cm}$ & $220 \mathrm{~cm}$ & - \\
P824GC & Paleo-Dnjepr & $44^{\circ} 39.06^{\prime}$ & $3201.00^{\prime}$ & 1014 & $\sim 120 \mathrm{~cm}$ & $280 \mathrm{~cm}$ & $390 \mathrm{~cm}$ \\
\hline
\end{tabular}

of Mediterranean seawater $\sim 9800 \mathrm{yr}$ BP the clay deposits became brackish (Ross et al., 1970; Calvert et al., 1991). The brackish clay from the oxic period is overlain by a microlaminated organic-rich sapropel that marks the transition to marine coccolith ooze deposited after $\sim 3000 \mathrm{yr} \mathrm{BP}$, representing the recent anoxic period of the Black Sea.

The sedimentary sequences have been labelled according to the following chronology: Unit I represents the modern coccolith ooze, Unit IIa is the sapropel deposited during the anoxic brackish period, Unit IIb the sediment from the oxic brackish period, and Unit III is the deep limnic sediment (Ross and Degens, 1974; Arthur and Dean, 1998).

The abundance of methane in the Black Sea sediments results from the slow degradation of organic matter under anoxic conditions Brumsack, 1989; Arthur and Dean, 1998). Since the concentrations of electron acceptors such as oxygen, nitrate, and metal-ions like $\mathrm{Fe}(\mathrm{III})$ and $\mathrm{Mn}(\mathrm{IV})$ are typically low or absent in Black Sea sediments below the anoxic water column (Thamdrup et al., 2000), sulfate reduction and bicarbonate-based methanogenesis are the dominant terminal anaerobic pathways of organic matter degradation (Jørgensen et al., 2004). Most of the methane is therefore expected to be biogenic, as confirmed by stable isotope analyses (Amouroux et al., 2002; Michaelis et al., 2002).

Where free gas does not reach the surface but is dissolved in the pore water at depth, methane diffuses upwards into the sulfate zone, where it is oxidized in combination with sulfate reduction. In most marine shelf and slope sediments the overlapping methane and sulfate profiles form a distinct sulfate-methane transition zone (SMTZ) (Devol and Anderson, 1984; Niewöhner et al., 1998) in which AOM and sulfate reduction co-occur. Earlier studies of the SMTZ in the Black Sea revealed that the methane profile is tailing up towards the sediment surface (Reeburgh et al., 1991; Jørgensen et al., 2001), thus creating an extended SMTZ. This broad zone of methane and sulfate coexistence indicates that microbial turnover of methane is for some reason particularly sluggish (Jørgensen et al., 2001) and therefore provides an interesting opportunity to study the regulation of SRR and $\mathrm{AOM}$ rates and the controls on $\mathrm{AOM}$ distribution.

In Black Sea sediments AOM provides the energy substrate for $7-18 \%$ of the total sulfate reduction and is the main source of $\mathrm{H}_{2} \mathrm{~S}$ formation at depth (Jørgensen et al., 2004). The occurrence of a deep sink for $\mathrm{H}_{2} \mathrm{~S}$ below the SMTZ, which is related to a high content of reactive iron in the for-

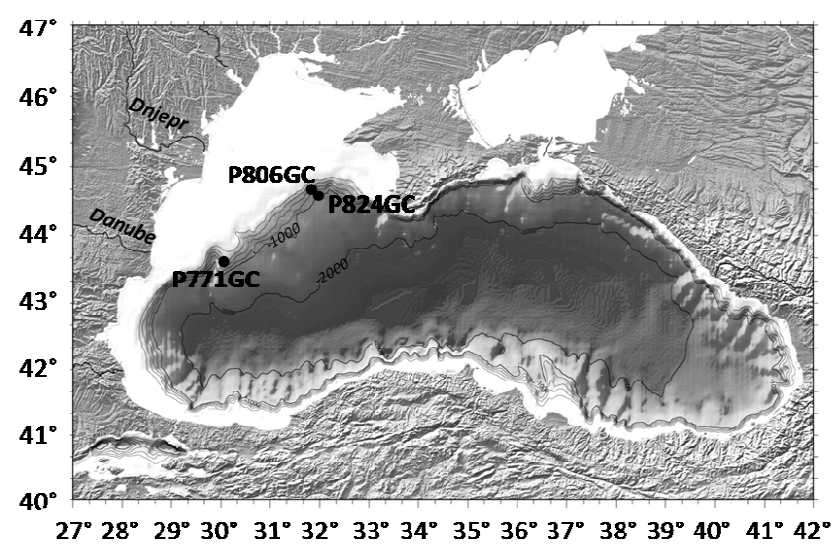

Fig. 1. Map of the Black Sea with the three different sampling sites of the gravity cores.

merly limnic sediments, might play a role in regulating SRR and AOM activity in Black Sea sediments.

Among the questions addressed in this study were, a) how is methane oxidation influenced by the unique environmental conditions in the Black Sea and b) what are the reasons for the sluggish AOM rates which lead to methane tailing in these sediments. It is further investigated how SRR and AOM rates are distributed in the extended SMTZ, and what role methanogenesis plays in this environment.

\section{Methods}

\subsection{Sample collection}

Sediment cores were sampled with a gravity corer (GC) during cruise 317/3 with RV Poseidon in October 2004 at three stations in the Western Black Sea (Fig. 1, Table 1). The 5-m long cores were cut into 1-m sections on deck. At the top of each 1-m section a methane sample was immediately taken to check for the potential loss of dissolved methane before detailed sub-sampling. All core sections were sub-sampled for chemical analyses and for microbial process rate measurements at the latest $24 \mathrm{~h}$ after retrieval of the core. 


\subsection{Chemical analyses}

\subsubsection{Methane concentrations}

Methane concentrations were measured in $3 \mathrm{~cm}^{3}$ sediment samples collected with $5 \mathrm{ml}$ cut-off syringes and sealed in serum vials that contained $6 \mathrm{ml} \mathrm{NaOH}(2.5 \% \mathrm{w} / \mathrm{v})$. The samples were shaken and stored to achieve equilibrium between the slurry and the headspace. The methane concentration in the headspace was determined by gas chromatography (5890A, Hewlett Packard) using a packed stainless steel Porapak-Q column (6ft., 0.125 in., 80/100 mesh, Agilent Technology) and a flame ionization detector. The column temperature was $40^{\circ} \mathrm{C}$, and helium was used as a carrier gas at a flow rate of $30 \mathrm{ml} \mathrm{min}^{-1}$. The detection limit for methane was $0.006 \mathrm{mM}$. The methane profile from sub-samples was compared to the samples taken immediately from the 1-m sections and showed that the loss of methane during storage was not significant in the SMTZ.

\subsubsection{Sulfate concentrations}

Sulfate concentrations were measured in $5 \mathrm{~cm}$ depth intervals from pore water collected by pressure-filtration (Millipore nitrocellulose filters $0.45 \mu \mathrm{m}$ ) with nitrogen (Iversen and Jørgensen, 1985; Fossing et al., 1990). $1 \mathrm{ml}$ of the pore water was directly fixed in $0.25 \mathrm{ml} \mathrm{ZnCl} 2(2 \% \mathrm{w} / \mathrm{v})$ to trap dissolved sulfide and prevent oxidation. The concentration of sulfate in the pore water was analyzed by non-suppressed anion exchange chromatography (Waters 510 HPLC Pump; Waters IC-Pak $50 \times 4.6 \mathrm{~mm}$ anion exchange column; Waters 430 Conductivity detector). Isophtalic acid ( $1 \mathrm{mM}, \mathrm{pH} 4.6)$ in methanol $(10 \% \mathrm{v} / \mathrm{v})$ was used as eluant. The detection limit for sulfate was $0.2 \mathrm{mM}$.

\subsubsection{Hydrogen sulfide}

Hydrogen sulfide was determined from the pore water samples fixed with $\mathrm{ZnCl}_{2}(2 \% \mathrm{w} / \mathrm{v})$ by the diamine complexation method described by (Cline, 1969). The sulfide concentration was measured by spectrophotometry at a wavelength of $670 \mathrm{~nm}$ and the detection limit was $0.001 \mathrm{mM} \mathrm{H}_{2} \mathrm{~S}$.

\subsubsection{Dissolved inorganic carbon (DIC)}

The concentration of DIC in pore water was measured on samples sealed in headspace-free glass vials poisoned with $\mathrm{HgCl}_{2}(0.25 \mathrm{mM})$, and stored at $10^{\circ} \mathrm{C}$. The samples were analyzed by flow injection (Hall and Aller, 1992) using $\mathrm{HCl}$ $(30 \mathrm{mM})$ and $\mathrm{NaOH}(10 \mathrm{mM})$ as eluants and a conductivity detector (VWR scientific, model 1054). All measured DIC values were far above the detection limit, which was $<0.2 \mathrm{mM}$.

\subsubsection{Density and porosity}

Samples for density and porosity were taken in $10 \mathrm{ml}$ cut-off syringes and $8 \mathrm{~cm}^{3}$ of sediment was weighed before and after drying at $60^{\circ} \mathrm{C}$. The density was calculated as the wet weight per $\mathrm{cm}^{3}$ and the porosity was determined from the loss of water per $\mathrm{cm}^{3}$ after the sediment was completely dried.

\subsubsection{Acetate concentrations}

Concentrations of acetate were measured from undiluted squeezed pore water that was stored frozen and thawed immediately before measurement. Samples were analyzed on a Dionex ICS-2000 Ion Chromatography System equipped with a Dionex AS50 autosampler at $4{ }^{\circ} \mathrm{C}$. Determinations of VFA species were carried out using a Dionex Anion SelfRegenerating Suppressor (ASRS-ULTRA II 4-mm) unit in combination with a conductivity detector.

\subsubsection{Dissolved iron}

The concentration of $\mathrm{Fe}^{2+}$ in pore water was analyzed with Ferrozine $\left(1 \mathrm{~g} \mathrm{~L}^{-1}\right.$ in $50 \mathrm{mM}$ HEPES buffer, $\left.\mathrm{pH} 7\right)$ according to (Stookey, 1970) by spectrophotometry at $562 \mathrm{~nm}$.

\subsubsection{Total reactive iron}

Total reactive iron (reduced iron reactive to sulfide) was extracted from the sediment with dithionite-citrate-acetic-acid (Canfield, 1989). The dithionate extracts were analyzed for total iron $\left(\mathrm{Fe}^{2+}\right.$ and $\left.\mathrm{Fe}^{3+}\right)$ with Ferrozine plus $1 \%(\mathrm{w} / \mathrm{v})$ hydroxylamine hydrochloride.

\subsubsection{Organic carbon and carbonate}

Total carbon (TC) and organic carbon $\left(\mathrm{C}_{\mathrm{org}}\right)$ were measured by high-temperature combustion (Carlo Erba NA-1500 Elemental Analyzer) using treatment with concentrated $\mathrm{HCl}$ for removal of inorganic carbon. Calcium carbonate content of each sample was calculated from the difference between TC and $\mathrm{C}_{\text {org }}$ as a weight percentage of dry sediment $\left(\% \mathrm{CaCO}_{3}\right)$.

\subsubsection{Diffusional fluxes}

Fluxes of methane, sulfate and sulfide were calculated from the slopes of the concentration profile into the SMTZ and the respective diffusion coefficients according to Fick's first law of diffusion:

$J=\phi \times D_{S} \times \frac{d C}{d z}$

where $J$ is the diffusive flux [ $\mathrm{mmol} \mathrm{m}^{-2} \mathrm{~d}^{-1}$ ], $\phi$ the porosity, $D_{s}$ is the diffusion coefficient in the sediment $\left[\mathrm{cm}^{2} \mathrm{~d}^{-1}\right]$, and $d C / d z$ is the concentration gradient $\left[\mu \mathrm{mol} \mathrm{cm}^{-4}\right]$. Diffusion coefficients at the respective in situ temperature and salinity were calculated from Schulz (2000), corrected for porosity 
of the sediment with $n=2$ for $\phi<0.7$ and $n=3$ for $\phi \geq 0.7$ according to Iversen and Jørgensen (1993):

$$
D_{S}=\frac{D}{1+n(1-\phi)}
$$

\subsubsection{Stable isotopes}

For stable isotope analyses gases were stripped from pore water according to (McAullife, 1971). The gas was stored as a headspace in inverted crimp top Wheaton vials by displacement of a preservative solution that consisted of $\mathrm{KCl} 10 \%$ $(\mathrm{w} / \mathrm{v})$ in de-ionized water adjusted to $\mathrm{pH} 1 \mathrm{using} \mathrm{HCl}$. Analysis of ${ }^{13} \mathrm{C} /{ }^{12} \mathrm{C}$ ratios was conducted by isotope ratio monitoring gas chromatography mass spectrometry (GC-C-IRMS) using a Varian 3400 GC coupled to a Thermoelectron XP mass spectrometer via a Gas Bench interface. Methane was separated on a PLOT Q capillary column $(0.32 \mathrm{~mm} \times 30 \mathrm{~m})$ and combusted to $\mathrm{CO}_{2}$ at $1000^{\circ} \mathrm{C}$ in a ceramic reactor containing $\mathrm{Cu}$ and $\mathrm{Pt}$ wires. A high purity blend of $1 \% \mathrm{O}_{2}$ in helium was fed into the reactor at $\sim 0.1 \mathrm{ml} \mathrm{min}^{-1}$ to ensure quantitative conversion of $\mathrm{CH}_{4}$ to $\mathrm{CO}_{2}$. The $\mathrm{H}_{2} \mathrm{O}$ produced was removed using a Nafion membrane. Accuracy and precision of $\delta^{13} \mathrm{C}_{-} \mathrm{CH}_{4}$ analysis by this method were both better than \pm 0.2 based upon replicate analysis of a BOC alpha gravimetric $\mathrm{CH}_{4}$ standard. Stable isotope ratios are reported in the standard $\delta^{13} \mathrm{C}$ notation relative to Vienna Pee Dee Belemnite (VPDB).

\subsection{Microbial process rates}

\subsubsection{Anaerobic oxidation of methane (AOM)}

Sediment for AOM measurements was either a) taken for each $5 \mathrm{~cm}$ depth interval with glass tubes in three parallel $5 \mathrm{~cm}^{3}$ samples and sealed headspace-free with butyl stoppers (P771GC), or b) sampled in acrylic core liners with injection holes at $2 \mathrm{~cm}$ depth intervals (P806GC and P824GC). ${ }^{14} \mathrm{C}$-methane tracer $(1.35 \mathrm{KBq})$ was injected into each sample and incubated for 20-24 h at the in situ temperature of the SMTZ. After incubation the sediment was transferred to glass vials containing $25 \mathrm{ml} \mathrm{NaOH}(2.5 \% \mathrm{w} / \mathrm{v})$ and suspended completely to stop microbial activity. To determine the detection limit of the rate measurement, five control samples per core were stopped immediately after tracer injection. To calculate AOM rates, the methane concentration in each sample was analyzed by gas chromatography and the pool of ${ }^{14} \mathrm{C}$-methane was measured by combustion of the headspace and scintillation counting. The produced ${ }^{14} \mathrm{C}-\mathrm{CO}_{2}$ in the sediment was extracted through acidic diffusion, trapped in scintillation vials with phenylethylamine, and the radioactivity was counted (Treude et al., 2003).

\subsubsection{Sulfate reduction rate (SRR)}

The samples for SRR measurements were taken as described for AOM, injected with ${ }^{35} \mathrm{~S}$-sulfate tracer $(500 \mathrm{kBq})$, and in- cubated for $20-24 \mathrm{~h}$ at in situ temperature. The microbial activity was stopped by mixing with $20 \mathrm{ml} \mathrm{ZnAc} \mathrm{(20 \%} \mathrm{w/v).}$ Samples were analyzed by the cold distillation method described by (Kallmeyer et al., 2004), where the total radiolabelled reduced inorganic sulfur (TRIS) is determined in relation to the total radioactive sulfate pool (all units in decays per minute) that remained in the sample. SRR in $\mathrm{nmol} \mathrm{cm} \mathrm{cm}^{-3} \mathrm{~d}^{-1}$ was calculated using the following equation (Jørgensen, 1978):

$$
\mathrm{SRR}=\left[\mathrm{SO}_{4}^{2-}\right] \times \frac{{ }^{35} \mathrm{~S}-\mathrm{TRIS}}{{ }^{35} \mathrm{~S}-\mathrm{TRIS}+{ }^{35} \mathrm{~S}-\mathrm{SO}_{4}^{2-}} t^{-1} \times 1.06
$$

where $\left[\mathrm{SO}_{4}^{2-}\right]$ is the sulfate concentration in $\mu \mathrm{mol} \mathrm{cm}{ }^{-3}, t$ is the incubation time (in days), and 1.06 is an estimated fractionation factor between ${ }^{35} \mathrm{~S}$ and the ${ }^{32} \mathrm{~S}$ isotope. Because of high variability of the remaining sulfate tracer that was recovered in the samples for core P771GC the SRR was calculated using the injected tracer activity minus produced ${ }^{35} \mathrm{~S}$-TRIS as the ${ }^{35} \mathrm{~S}_{-} \mathrm{SO}_{4}^{2-}$ pool.

The detection limit of SRR and AOM rates was determined for each core by the produced ${ }^{14} \mathrm{C}-\mathrm{CO}_{2}$ or ${ }^{35} \mathrm{~S}$-TRIS in zero time controls plus 2 times their standard deviation (Ferdelman et al., 1999). Three replicate measurements for each depth are presented in the graphs and only values above the detection limit are shown.

\subsubsection{Bicarbonate methanogenesis}

Bicarbonate methanogenesis rates were measured by injecting ${ }^{14} \mathrm{C}$-bicarbonate (activity $38 \mathrm{kBq}$ ) at 2-cm depth intervals into subcores taken in acrylic core liners. After incubation for 6 to $24 \mathrm{~h}$ at in situ temperature the incubations were terminated by transferring $2 \mathrm{~cm}$ slices of the subcores to glass vials $(30 \mathrm{ml})$ containing $7 \mathrm{ml}$ of $\mathrm{NaOH}(1 \mathrm{M})$. In the laboratory, the vial headspace was flushed (carrier gas $95 \% \mathrm{~N}_{2}: 5 \% \mathrm{O}_{2}$ at $70 \mathrm{ml} / \mathrm{min}$ for $20 \mathrm{~min}$.) through a $\mathrm{CO}_{2}$-trap (Supelco, UK) and over copper oxide at $800^{\circ} \mathrm{C}$ in a furnace (Carbolite, UK) to oxidize any produced ${ }^{14} \mathrm{CH}_{4}$ to ${ }^{14} \mathrm{CO}_{2}$. The ${ }^{14} \mathrm{CO}_{2}$ was trapped in Optiphase HiSafe-3 and $\beta$-phenethylamine (93:7), and measured in a scintillation counter (Perkin Elmer, UK). Activity rates were calculated from the label turnover times applied to the relevant cold-pool concentrations of DIC.

\subsubsection{Acetate methanogenesis}

To determine acetate methanogenesis rates the samples were obtained as for bicarbonate methanogenesis, but were injected with ${ }^{14} \mathrm{C}$-acetate tracer (activity $20 \mathrm{kBq}$ ) at 2-cm depth intervals and also incubated for 6 to $24 \mathrm{~h}$ at in situ temperature. Samples were processed the same way as described above for bicarbonate methanogenesis. Rates were calculated from the label turnover times and the relevant cold-pool concentrations of acetate. 


\subsection{Microbiology}

\subsubsection{Acridine orange direct counts (AODC)}

AODC was used to determine the total number of microorganisms. A $1 \mathrm{~cm}^{3}$ sample of sediment was preserved in serum vial combusted in an oven at $800^{\circ} \mathrm{C}$, containing $9 \mathrm{ml}$ formaldehyde $(2 \% \mathrm{v} / \mathrm{v}$ in artificial seawater, filter sterilized $0.2 \mu \mathrm{m})$. Three replicate sub-samples $(5-25 \mu \mathrm{l})$ were stained for $3 \mathrm{~min}$ with $50 \mu \mathrm{l}$ acridine orange $(0.1 \% \mathrm{w} / \mathrm{v})$ in $10 \mathrm{ml}$ formaldehyde $(2 \% \mathrm{v} / \mathrm{v}$ in artificial seawater, filter sterilized $0.1 \mu \mathrm{m})$ and vacuum filtered through a black polycarbonate membrane filter $(0.22 \mu \mathrm{m})$. Paraffin oil mounted membrane filters were viewed under incident UV illumination with a Zeiss Axioskop epiflourescence microscope at X1000. Both unattached cells and cells attached to particles were counted and the number of attached cells was doubled to account for cells hidden from view (Goulder, 1977). Dividing and divided cells were counted separately to provide an index of the growth potential of the populations.

\section{Results}

\subsection{Pore water concentrations}

Depth profiles of methane and sulfate concentrations as substrates of AOM mediated by sulfate reduction and the products sulfide and DIC from the three gravity cores are presented in Fig. 2. In core P771GC the marine deposit of laminated coccolith ooze at the top with an organic carbon content of 3\% is overlying a sapropel layer, characterized by a maximum of organic carbon of $13 \%$ dry weight and a minimum of $\mathrm{CaCO}_{3}$ which dropped from $\sim 50$ to $\sim 10 \%$.

At $\sim 70 \mathrm{~cm}$ the dark sapropel changed into light-grey brackish clay along with a drop in organic carbon and a high $\mathrm{CaCO}_{3}$ content of $\sim 60 \%$ at the interface. Below $160 \mathrm{~cm}$ depth the clay was marbled with darker sediment and contained black grains of greigite and dark laminations at $200 \mathrm{~cm}$ depth (Table 1).

The core was sampled on the slope of the Danube Canyon at a water depth of $680 \mathrm{~m}$ between stations 6 and 7 of the transect described by Jørgensen et al. (2004). Similar to the findings of those authors the methane profile of P771GC also showed an extended tailing up towards the sediment surface. High methane concentrations of $\sim 1.2 \mathrm{mM}$ were measured at $360 \mathrm{~cm}$ depth below which methane had been outgassing upon core recovery, as indicated by cracks in the sediment observed below $400 \mathrm{~cm}$ depth. The upwards diffusive flux of methane into the SMTZ was $19 \mu \mathrm{mol} \mathrm{m}^{-2} \mathrm{~d}^{-1}$ and a flux of $4 \mu \mathrm{mol} \mathrm{m}^{-2} \mathrm{~d}^{-1}$ remained above $230 \mathrm{~cm}$. The methane concentration approached zero at $\sim 70 \mathrm{~cm}$ depth, at the transition between the brackish and the marine sediments Unit IIb and IIa (Table 1).

Sulfate concentrations decreased nearly linearly from $25 \mathrm{mM}$ at the top of the core to a depth of $\sim 340 \mathrm{~cm}$, with a sulfate flux into the SMTZ of $149 \mu \mathrm{mol} \mathrm{m}^{-2} \mathrm{~d}^{-1}$. Sulfate was not entirely depleted below this depth but a constant concentration of $\sim 1 \mathrm{mM}$ apparently remained below $350 \mathrm{~cm}$. Sulfide concentrations in core P771GC were low for a methane rich environment and did not exceed $0.2 \mathrm{mM}$ (Fig. 2a). The peak of $\mathrm{H}_{2} \mathrm{~S}$ at $\sim 100 \mathrm{~cm}$ depth was located at the top of the limnic sediment in the upper part of the SMTZ, at a notably shallower depth than expected from the methane and sulfate profiles. $\mathrm{H}_{2} \mathrm{~S}$ diffusion occurred both upwards and downwards in the sediment, with similar fluxes towards the sediment surface $\left(12 \mu \mathrm{mol} \mathrm{m}^{-2} \mathrm{~d}^{-1}\right)$ and towards deeper sediment $\left(13 \mu \mathrm{mol} \mathrm{m}^{-2} \mathrm{~d}^{-1}\right)$. DIC concentrations were also rather low, increasing steadily from the top of the core to maximum values of $\sim 8 \mathrm{mM}$ at $270 \mathrm{~cm}$ depth, coinciding with the horizon where $\mathrm{H}_{2} \mathrm{~S}$ was depleted.

Core P806GC was collected on the shelf edge of the palaeo Dnjepr Delta, on the flank of a ridge that was lined with methane seeps at the top (Naudts et al., 2006). The core was covered by a thin sapropel at the top followed by a dense shell layer at $\sim 10 \mathrm{~cm}$ depth and the transition to lightgray brackish clay. A second shell layer was found at 80 to $140 \mathrm{~cm}$ depth (Table 1). The organic carbon and $\mathrm{CaCO}_{3}$ content were between $0-2 \%$ and $8-30 \%$ respectively, decreasing with depth. Below the second shell layer the sediment consisted of silty fine-grained sand that contained gas cracks from $220 \mathrm{~cm}$ downwards, consistent with the methane profile which indicated outgassing below $\sim 200 \mathrm{~cm}$ depth. The methane flux up into the SMTZ was $98 \mu \mathrm{mol} \mathrm{m}^{-2} \mathrm{~d}^{-1}$, which is much higher than in core P771GC. The methane and sulfate profiles exhibited a similar pattern of an extended SMTZ with methane tailing up towards the sediment surface.

The sulfate profile was linear from the top of the core down to a depth of $180 \mathrm{~cm}$, with a flux of $145 \mu \mathrm{mol} \mathrm{m}^{-2} \mathrm{~d}^{-1}$ into the SMTZ, 1.5 times higher than the methane flux. The residual pool of sulfate below the SMTZ was smaller than in core P771GC, approximately at the detection limit of $0.2 \mathrm{mM}$. The $\mathrm{H}_{2} \mathrm{~S}$ concentration at the top of the core $(0.2 \mathrm{mM})$ was similar to that of core P771GC, but the sulfide fluxes were higher $\left(38 \mu \mathrm{mol} \mathrm{m}^{-2} \mathrm{~d}^{-1}\right.$ towards the top and $68 \mu \mathrm{mol} \mathrm{m}{ }^{-2} \mathrm{~d}^{-1}$ towards depth) because of the higher $\mathrm{H}_{2} \mathrm{~S}$ peak of $\sim 2 \mathrm{mM}$ that occurred in the lower part of the SMTZ. The linear increase of DIC concentration again reached maximum values in the zone of sulfide depletion at $\sim 200 \mathrm{~cm}$ depth and, like the $\mathrm{H}_{2} \mathrm{~S}$ concentrations, they were also much higher than in core $771 \mathrm{GC}$.

Core P824GC sampled in the deeper part of the Black Sea on mid-slope contained a thick sapropel layer with laminations that changed into uniform grey clay of the brackish period at $120 \mathrm{~cm}$ depth (Table 1). As in core P771GC, the organic carbon content of 3-5\% in the coccolith ooze increased to $\sim 10 \%$ in the sapropel layer and dropped to $\sim 2 \%$ at the transition to the brackish clay. Unlike in P771GC and P806GC the peak of the $\mathrm{CaCO}_{3}$ content was located much deeper in relation to the methane and sulfate profiles, around $200 \mathrm{~cm}$ depth. The most notable difference of P824GC is that 

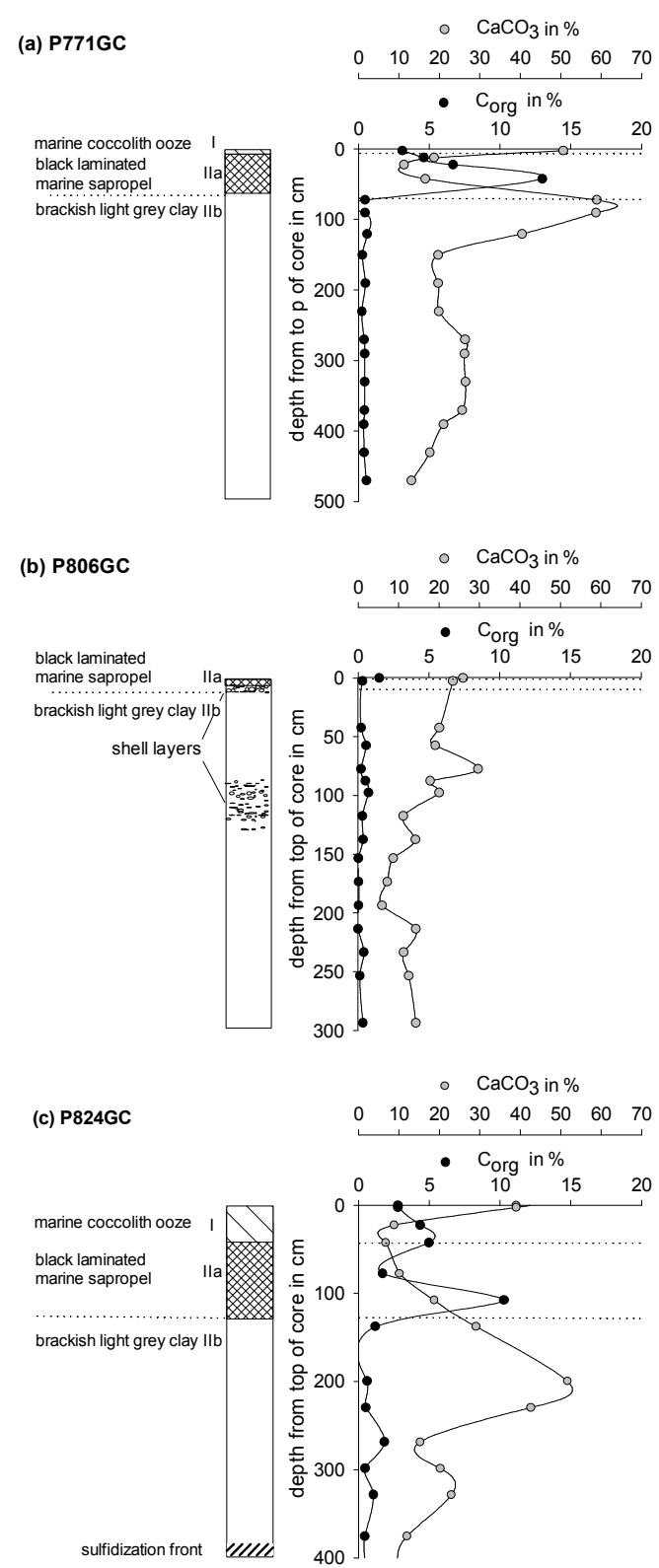
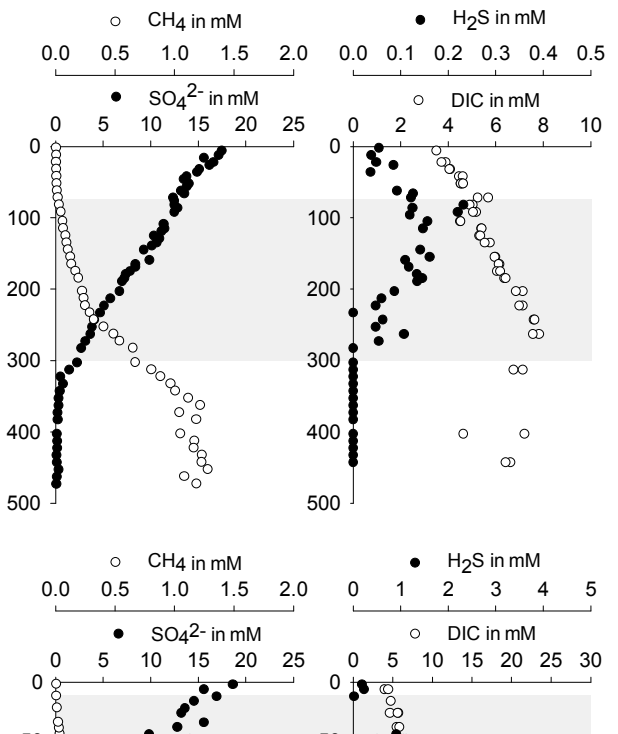

500
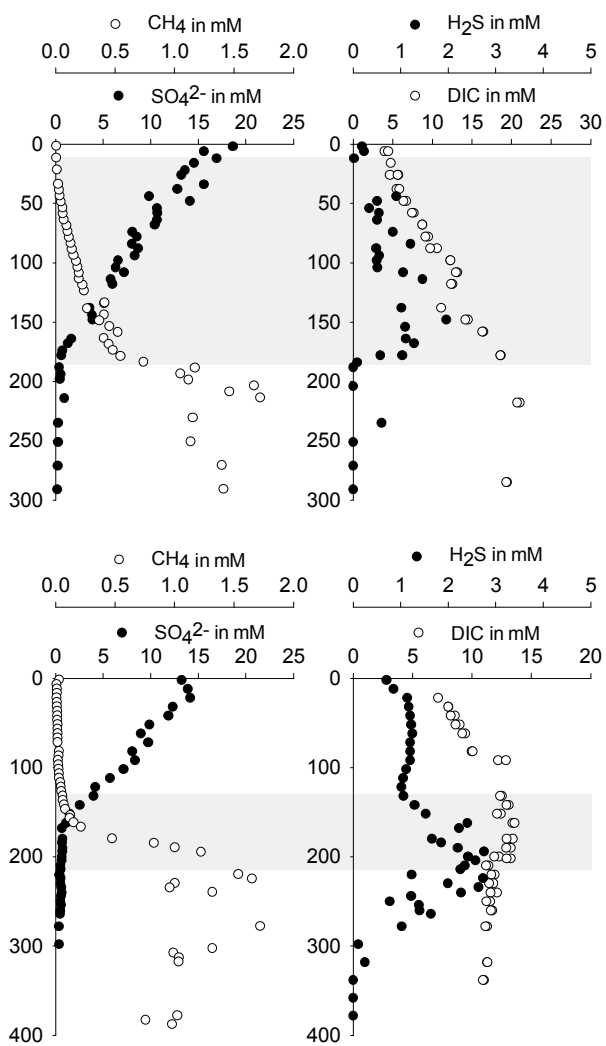

Fig. 2. Stratigraphy and pore water chemistry in gravity cores from the three stations $\left(\mathrm{CaCO}_{3}\right.$ and $\mathrm{C}_{\text {org }}$ are both in $\%$ of total dry weight). The brackish-marine transition is indicated by a dotted line and the SMTZ is shaded in grey. The change from brackish to entirely limnic conditions has not been determined but based on previous data (Jørgensen et al., 2004) is expected to be $\sim 80 \mathrm{~cm}$ into the brackish sediment. The top of the core is not identical with the sediment surface because some sediment might have been lost by coring.

the methane profile did not show such a pronounced upwards tailing as at the other two sites, and resembled more the typical concave upwards pattern observed in most marine environments, forming a distinct SMTZ at 120 to $170 \mathrm{~cm}$ depth. The methane flux into the SMTZ was $126 \mu \mathrm{mol} \mathrm{m}^{-2} \mathrm{~d}^{-1}$, the highest of the three sites. Sediment cracks indicating methane super-saturation were observed from $>280 \mathrm{~cm}$ depth although the methane concentration profile would suggest outgassing already from $>220 \mathrm{~cm}$ depth.
The pore water sulfate profile of core P824GC was very similar to that measured in P806GC, with a concentration of $\sim 15 \mathrm{mM}$ at the top of the core and a sulfate flux into the SMTZ of $301 \mu \mathrm{mol} \mathrm{m}^{-2} \mathrm{~d}^{-1}$. Similar to P771GC sulfate was not completely depleted below $168 \mathrm{~cm}$ depth, but concentrations of $<0.6 \mathrm{mM}$ remained and decreased only gradually with depth.

DIC concentrations increased with depth down through the marine deposits at the top of the core attaining a maximum concentration of $14 \mathrm{mM}$ at the bottom of the SMTZ. 


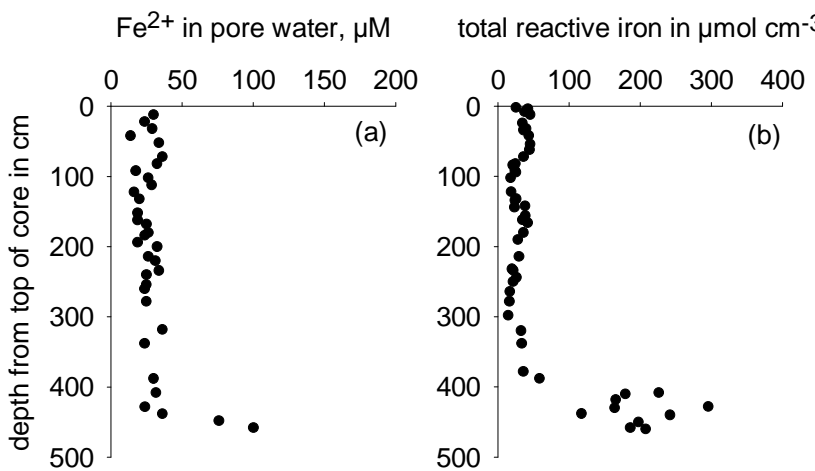

Fig. 3. Iron concentrations in core P824GC: (a) dissolved iron in the pore water; (b) total reactive iron in the solid phase.

In the limnic part of the sediment DIC decreased slightly to $\sim 12 \mathrm{mM}$.

The pore water concentration of $\mathrm{H}_{2} \mathrm{~S}$ was relatively constant at $\sim 1 \mathrm{mM}$ in the upper $20-100 \mathrm{~cm}$ of the core, decreasing only at the very top of the core. In relation to methane and sulfate, the $\mathrm{H}_{2} \mathrm{~S}$ maximum of $3 \mathrm{mM}$ at $200 \mathrm{~cm}$ depth was situated deeper than in the other two cores, even below the SMTZ, and was depleted at a depth of $330 \mathrm{~cm}$.

The concentrations of iron in the pore water and in the solid phase of core P824GC are presented in Fig. 3. Dissolved $\mathrm{Fe}^{2+}$ showed a steep increase below a depth of $\sim 430 \mathrm{~cm}$, forming a distinct iron diffusion front at this depth. Since sulfide is present in the zone above $400 \mathrm{~cm}$ the constant $\mathrm{Fe}^{2+}$ values down to this depth are most likely not real concentrations but are representing a background of the measurement. In the solid phase, reactive iron concentrations of up to $45 \mu \mathrm{mol} \mathrm{cm}{ }^{-3}$ were measured in the top $100 \mathrm{~cm}$ of the core, with a local minimum at the transition from the limnic to marine sediment. Below the sapropel layer, reactive iron concentrations were $<40 \mu \mathrm{mol} \mathrm{cm}{ }^{-3}$, with lowest values occurring between 200 and $300 \mathrm{~cm}$ depth. Reactive iron increased below $300 \mathrm{~cm}$, with a steep increase below $390 \mathrm{~cm}$ reaching up to $300 \mu \mathrm{mol} \mathrm{cm}{ }^{-3}$ at $430 \mathrm{~cm}$ depth. In the same horizon as this peak of reactive iron, black bands of $\mathrm{FeS} \mathrm{oc-}$ curred in the sediment between depths of $390 \mathrm{~cm}$ and $440 \mathrm{~cm}$.

\subsection{Microbial process rates and stable isotopes}

Rates of AOM, SRR and methanogenesis measured at station P771GC are shown in Fig. 4. Rates of AOM were low in the top $0-175 \mathrm{~cm}$, below which rates increased to reach a maximum of $5.6 \mathrm{nmol} \mathrm{cm}^{-3} \mathrm{~d}^{-1}$ at $250 \mathrm{~cm}$ depth. A distinct AOM peak was not observed. Instead, rates of $\sim 0.5$ to $4 \mathrm{nmol} \mathrm{cm}^{-3} \mathrm{~d}^{-1}$ were measured throughout the lower part of the core. As discussed below, however, it is not clear whether these values represent actual AOM activities.

Two peaks of sulfate reduction were detected, one occurring at $200 \mathrm{~cm}$ depth $\left(3-7 \mathrm{nmol} \mathrm{cm}^{-3} \mathrm{~d}^{-1}\right)$ and the other at $350 \mathrm{~cm}$ depth $\left(\sim 9 \mathrm{nmol} \mathrm{cm}{ }^{-3} \mathrm{~d}^{-1}\right)$ near the $\mathrm{SO}_{4}^{2-}$ depletion boundary. Low SRR were also detected between these peaks, yet the pattern of SRR did not reflect the profile of AOM. The lack of high rates at the top of the core (cf. Weber et al., 2001) is probably due to the loss of the more active surface sediment during gravity coring.

Bicarbonate-based methanogenesis was analyzed throughout the core, but rates were not detectable. Instead, acetatebased methanogenesis was found in the sulfate zone in the upper $100 \mathrm{~cm}$ of the core, but these rates were extremely low, with a maximum of $4.3 \times 10^{-4} \mathrm{nmol} \mathrm{cm}^{-3} \mathrm{~d}^{-1}$. At the depth where AOM occurred, acetate-based methanogenesis rates were below the detection limit of the radiotracer method. The occurrence of acetate-based methanogenesis at $50-100 \mathrm{~cm}$ was accompanied by high acetate concentrations of up to $30 \mu \mathrm{M}$, whereas other VFAs, such as formate or lactate, had concentrations below $10 \mu \mathrm{M}$ throughout the core. The total number of cells at the top of the core was $2.5 \times 10^{8}$ per $\mathrm{cm}^{3}$ and decreased with depth, most steeply in the upper $70 \mathrm{~cm}$.

The methane isotopic signal was most negative below the SMTZ, consistent with a preferential consumption of ${ }^{12} \mathrm{C}$ $\mathrm{CH}_{4}$ during $\mathrm{AOM}$, thus changing the $\delta^{13} \mathrm{C}$ of the methane from $-88 \%$ in the deep limnic sediment to $-78 \%$ o within the SMTZ. The $\delta^{13} \mathrm{C}_{-} \mathrm{CH}_{4}$ values above the inflection point at $210 \mathrm{~cm}$ suggest a change in either the rate or the process by which methane is being consumed above this depth. The $\delta^{13} \mathrm{C}-\mathrm{CO}_{2}$ values, controlled by AOM as well as by SRR, did not reflect this trend and varied around values of $-30 \%$.

The distribution of microbial process rates in core P806GC showed distinct peaks of AOM and SRR at similar depth (Fig. 5). AOM activity occurred in a $\sim 70 \mathrm{~cm}$ wide zone with a maximum rate of $\sim 2.4 \mathrm{nmol} \mathrm{cm}{ }^{-3} \mathrm{~d}^{-1}$ at $218 \mathrm{~cm}$. The peak of SRR at the bottom of the SMTZ $\left(\sim 0.8 \mathrm{nmol} \mathrm{cm}^{-3} \mathrm{~d}^{-1}\right)$ was much lower than the AOM rates at the same depth.

Bicarbonate-based methanogenesis rates were highest just above the AOM zone with a maximum of $0.06 \mathrm{nmol} \mathrm{cm}^{-3} \mathrm{~d}^{-1}$, and a rate of $0.015 \mathrm{nmol} \mathrm{cm}^{-3} \mathrm{~d}^{-1}$ at $\sim 200 \mathrm{~cm}$ depth, in the zone of maximum rates of AOM and sulfate reduction. Similar to P771GC, very low rates of acetate-based methanogenesis were detected, mostly in the sulfate zone in the top $100 \mathrm{~cm}$ of the core. Additional acetate-based methanogenesis activity occurred together with bicarbonate-based methanogenesis at $140 \mathrm{~cm}$ to $210 \mathrm{~cm}$ depth, with maximum methane production above the AOM zone. Rates of microbial processes were not determined below $230 \mathrm{~cm}$ depth.

The concentrations of acetate, formate and lactate were typically below $10 \mu \mathrm{M}$ in most of core P806GC, with the exception of higher lactate values (up to $27 \mu \mathrm{M}$ ) at $118 \mathrm{~cm}$ depth and acetate abundance of $\sim 10 \mu \mathrm{M}$ at $240 \mathrm{~cm}$ depth below the zone of AOM. The total number of microbial cells at the surface of the core was comparable to P771GC and decreased mainly in the top sediment. Below $36 \mathrm{~cm}$ depth, cell numbers remained almost constant at $\sim 3 \times 10^{7} \mathrm{cells} \mathrm{cm}^{-3}$. A slight decrease in cell numbers was observed only in the zone of AOM. 
P771GC AOM in nmol cm $\mathrm{d}^{-1} \quad$ SRR in nmol cm-3 d-1 bic-MTG in nmol cm-3 $\mathrm{d}^{-1} \quad$ ac-MTG in nmol cm-3 $\mathrm{d}^{-1}$

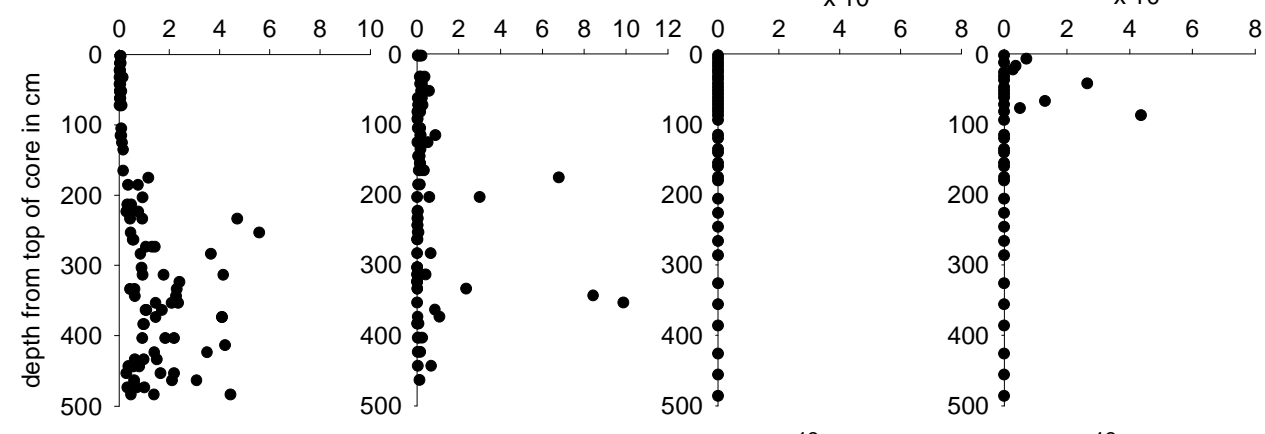

VFAs in $\mu \mathrm{M}$

AODC in log cells $\mathrm{cm}^{-3}$

$\delta^{13} \mathrm{C}-\mathrm{CH}_{4}$

$\delta^{13} \mathrm{C}-\mathrm{CO}_{2}$

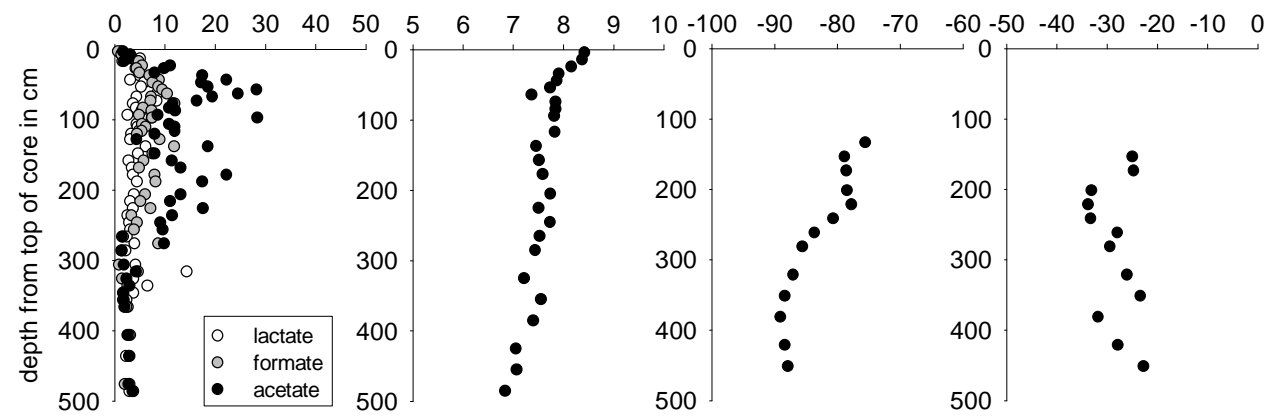

Fig. 4. Depth profiles from core P771GC of AOM, SRR, methanogenesis from bicarbonate (bic-MTG), methanogenesis from acetate (ac-MTG), volatile fatty acids (VFA), acridine orange direct cell counts (AODC), and $\delta^{13} \mathrm{C}$ stable isotope composition of methane and bicarbonate.

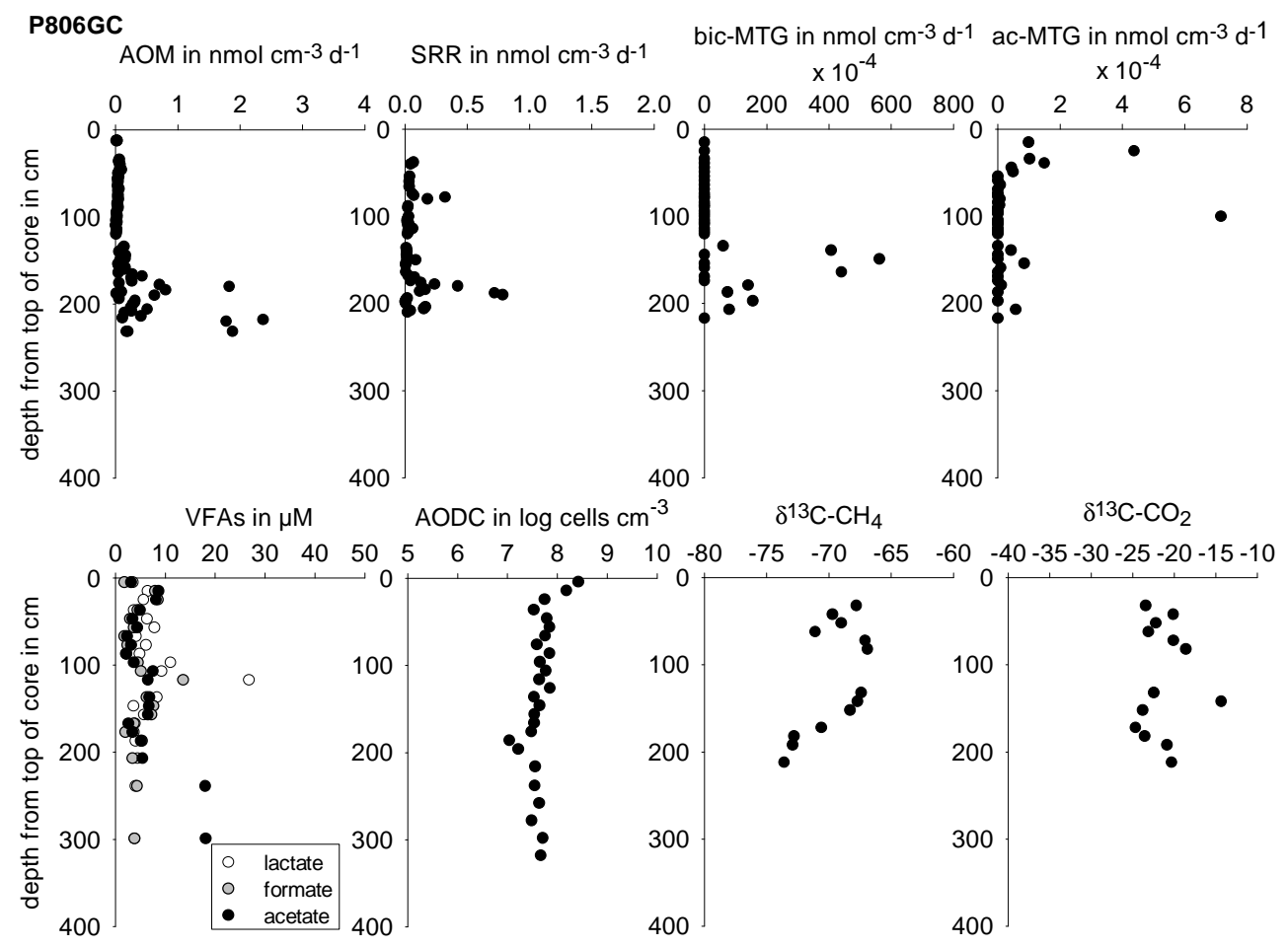

Fig. 5. Depth profiles from core P806GC, as described for Fig. 4. 
P824GC

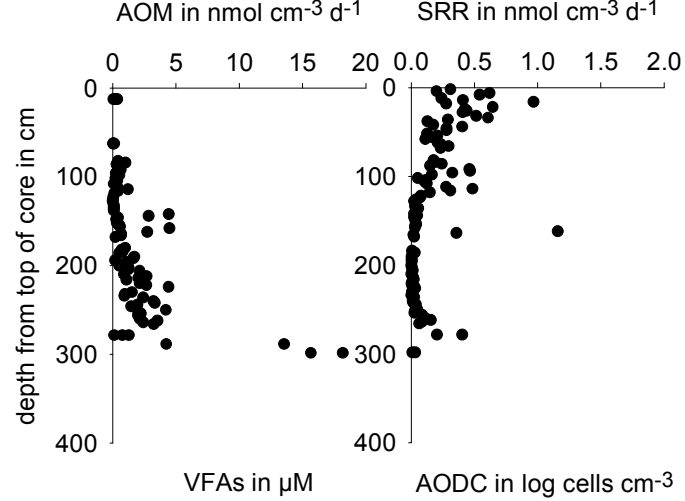

ac-MTG in $\mathrm{nmol} \mathrm{cm}^{-3} \mathrm{~d}^{-1}$ $\times 10^{-4}$
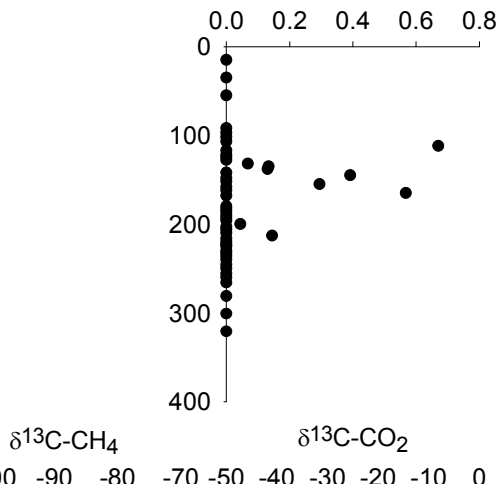

$\delta^{13} \mathrm{C}-\mathrm{CO}_{2}$
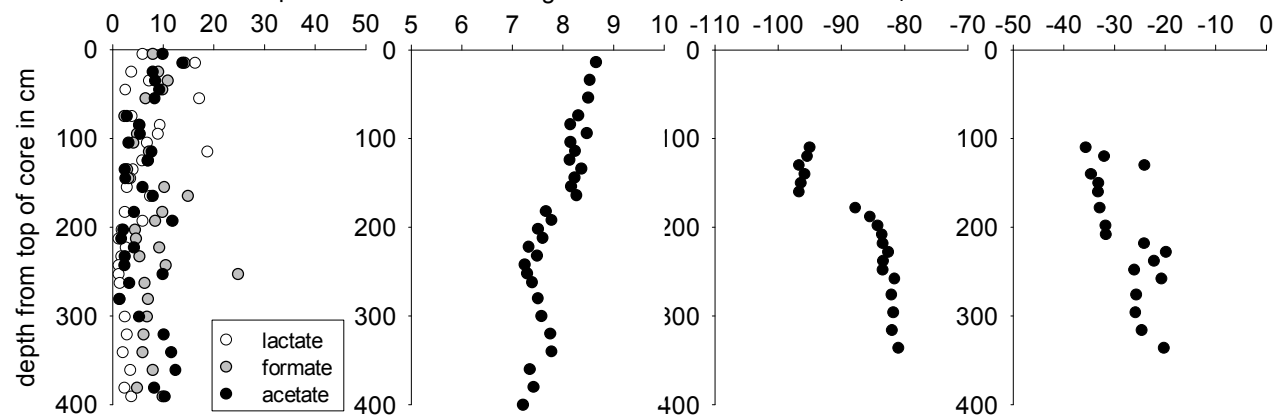

Fig. 6. Depth profiles from core P824GC, as described for Fig. 4.

The most negative $\delta^{13} \mathrm{C}-\mathrm{CH}_{4}$ values $(-73 \%$ ) were measured between 184 and $214 \mathrm{~cm}$ depth. A minor ${ }^{13} \mathrm{C}$ enrichement (up to $-70 \%$ o) occurred at shallower depth, most likely as a consequence of preferential oxidation of

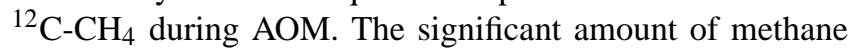
remaining above the SMTZ is consistent with the relatively small positive shift in $\delta^{13} \mathrm{C}_{-} \mathrm{CH}_{4}$ values. In addition, $\delta{ }^{13} \mathrm{C}$ $\mathrm{CH}_{4}$ values were not available for deeper sediments where higher methane concentrations can be found and, consequently, the contrast between $\delta^{13} \mathrm{C}$ values and methane above the SMTZ and in deeper sediments may be greater than these data suggest. Notably, $\delta^{13} \mathrm{C}$ values of DIC were not unusually negative indicating a lack of contribution of AOMderived $\mathrm{CO}_{2}$ to the pore water pool.

At station P824GC (Fig. 6), the profiles of methane and sulfate formed a distinct SMTZ from 130 to $170 \mathrm{~cm}$ depth, a zone which also showed increased microbial activity. The AOM peak around $150 \mathrm{~cm}\left(4.5 \mathrm{nmol} \mathrm{cm}^{-3} \mathrm{~d}^{-1}\right)$ represents the major zone of AOM activity, and coincided with increased sulfate reduction rates $\left(1.2 \mathrm{nmol} \mathrm{cm}^{-3} \mathrm{~d}^{-1}\right.$ at $162 \mathrm{~cm}$ ) at about the same depth. The AOM rates were measured down to $290 \mathrm{~cm}$ where a maximum rate of $\sim 18 \mathrm{nmol} \mathrm{cm}^{-3} \mathrm{~d}^{-1}$ was found. However, similar to core $\mathrm{P} 771 \mathrm{GC}$, it is not clear whether these rates reflect actual AOM activity.

Heterotrophic sulfate reduction in the top of the core exhibited low rates $\left(<1 \mathrm{nmol} \mathrm{cm}^{-3} \mathrm{~d}^{-1}\right)$ with a minimum at
$150-200 \mathrm{~cm}$. In addition to the methane-dependent SRR peak in the SMTZ, a second increase in ${ }^{35} \mathrm{~S}_{-} \mathrm{SO}_{4}^{2-}$ reduction was detected at $280 \mathrm{~cm}$ depth, but since sulfate might not be available at this depth it is not certain whether this turnover of radiotracer represents actual sulfate reduction.

Bicarbonate-based methanogenesis rates for core P824GC are not available, but acetate-based methanogenesis rates were very low (maximum $6.7 \times 10^{-5} \mathrm{nmol} \mathrm{cm}^{-3} \mathrm{~d}^{-1}$ ). In contrast to cores P771GC and P806GC, detectable rates did not occur in the upper part of the cores but instead between $130 \mathrm{~cm}$ and $200 \mathrm{~cm}$ depth. VFAs were measured throughout the core at concentrations $<20 \mu \mathrm{M}$. The total cell counts in core P824GC did not show the steep decrease of cell numbers at the top of the core as it was observed at the other two sites. The cell numbers decreased more gradually, exhibiting slight maxima at $165 \mathrm{~cm}$ and $340 \mathrm{~cm}$ depth, of which the shallower maximum coincided with enhanced rates of AOM and sulfate reduction.

Below the SMTZ, methane had $\delta^{13} \mathrm{C}$ values of -85 to $-81 \%$. At the SMTZ there was a sudden shift to highly negative $\delta^{13} \mathrm{C}$ values reaching $-97 \%$ at $160 \mathrm{~cm}$ depth. This extreme ${ }^{13} \mathrm{C}$-depletion at low concentrations of methane occurred in the zone where typically methane is expected to be $\delta^{13} \mathrm{C}$-enriched as a result of AOM. The highly negative $\delta^{13} \mathrm{C}-\mathrm{CH}_{4}$ values coincided partly with a negative shift in $\delta^{13} \mathrm{C}$-DIC values just above the maximum in DIC concentration. 


\section{Discussion}

Anaerobic oxidation of methane, sulfate reduction, and methanogenesis were investigated in three diffusive sedimentary environments of the Black Sea, where the SMTZ was situated below the sapropel in the brackish or limnic part of the sediment. In cores P771GC and P806GC the zones of major AOM activity were located $>100 \mathrm{~cm}$ below the marine-brackish transition in the limnic deposits, while in core P824GC it coincided with the boundary between the Holocene marine sapropel and the underlying lacustrine clay.

\subsection{AOM and SRR}

The most noticeable feature of the methane profiles in the Black Sea is that AOM does not consume the entire methane flux in a well-defined zone of major AOM activity. This apparent inefficiency results in an extended zone of methane and sulfate co-occurrence with tailing of pore water methane far up towards the sediment surface. This feature of a gradual oxidation of methane was observed previously in gravity cores from the western Black Sea (Reeburgh et al., 1991; Jørgensen et al., 2001) and was re-confirmed by the methane profile in core P771GC. It seems to be a common pattern that is also present in methane-rich sediments in other parts of the Black Sea, as suggested by its occurrence in core P806GC from an area of the Dnjepr Canyon. Jørgensen et al. (2001) described the methane-tailing as "sluggish" AOM. Microbial process rates in core P806GC determined by radiotracer experiments were indeed low, especially for SRR. However, in diffusion dominated systems at other continental margins AOM rates are mostly similarly low, and peak rates from the Black Sea, in particular in core P771GC with a very pronounced methane tailing, were in the same range (3-6 $\mathrm{nmol} \mathrm{cm}^{-3} \mathrm{~d}^{-1}$ ) as maximum AOM rates measured in the North Sea (Niemann et al., 2005) and Skagerrak (Parkes et al., 2007), where methane tailing did not occur.

The combined presence of methane and sulfate in an extended SMTZ should facilitate AOM activity and sulfate reduction also in shallower horizons. Yet, these processes were not evenly distributed within the SMTZ but occurred mainly in the lower part of the SMTZ. In contrast to the SMTZ of typical methane-rich marine sediments, where SRR and AOM rates occur in a distinct zone defined by the availability of the substrates, the AOM activity in cores P771GC and P824GC was spread over a broad sediment interval and was also detected at depths where sulfate was restricted to background values or was even not measurable. The occurrence of AOM below the main zone of activity is very unusual and questionable. In P824GC, where samples were collected throughout the core, the turnover of radioactive ${ }^{14} \mathrm{C}$ $\mathrm{CH}_{4}$ showed that the highest activity occurred at $140-160 \mathrm{~cm}$ depth (Fig. 7b) and that the rates at greater depths do not result from an increased fraction of methane turnover, but instead from the higher methane concentrations in the deeper

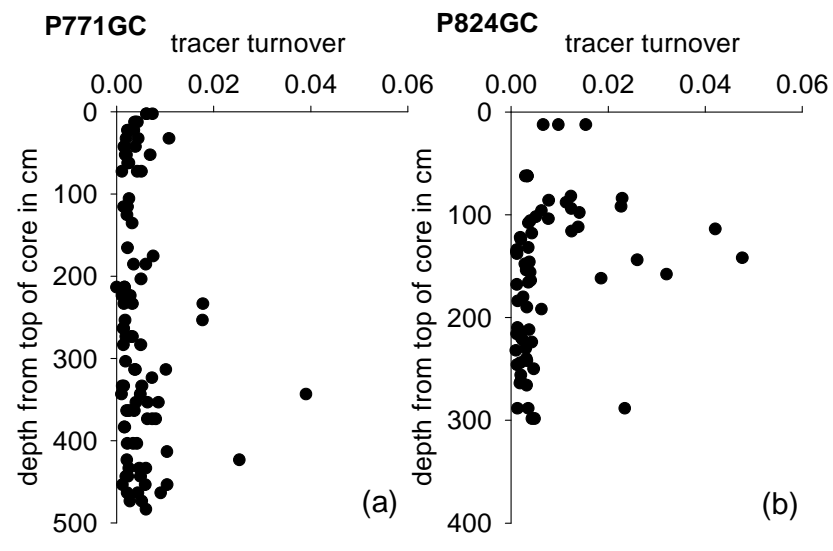

Fig. 7. Tracer turnover of ${ }^{14} \mathrm{C}$-labeled methane, calculated as the proportion of the total ${ }^{14} \mathrm{C}$-pool recovered as ${ }^{14} \mathrm{C}-\mathrm{CO}_{2}$ for cores P771GC and P824GC.

part of the core. Detection of ${ }^{14} \mathrm{C}-\mathrm{CO}_{2}$ at $\sim 290 \mathrm{~cm}$ depth could be a problem of defining the background radioactivity associated with the tracer incubation method at sites with low AOM activity. However, in P824GC there was also a peak in SRR activity at the same depth as the deep AOM activity, and sulfate-reducing bacteria were reported to be present in this horizon (Leloup et al., 2006). It therefore remains unclear whether AOM rates below $180 \mathrm{~cm}$ depth reflect actual activity. The measurements of ${ }^{14} \mathrm{CO}_{2}$ production in the lower part of core P771GC did show increased fractional ${ }^{14} \mathrm{C}_{-} \mathrm{CH}_{4}$ turnover (Fig. 7a). Whereas AOM rates in the deeper part of this core might be overestimated because of high methane concentrations, it appears likely that AOM is not confined to a distinct zone of activity.

A good correlation between AOM and SRR was observed in the shallowest core P806GC, in agreement with the observation of Jørgensen et al. (2001) who noted that the coupling of both processes is less distinct at greater water depth. The measured rates of AOM and SRR were confined to a narrow zone around $180 \mathrm{~cm}$ depth. However, this close coupling between AOM and SRR did not result in the formation of a well defined SMTZ or an effective oxidation barrier for methane diffusing into the AOM zone.

Despite relatively high rates of AOM and SRR in P771GC and the close coupling of these rates in P806GC, only core P824GC did not exhibit a pronounced tailing of methane. It was the only station with a distinct SMTZ, similar to the typical SMTZ found in most methane-bearing ocean margin sediments (Niewöhner et al., 1998; Hensen et al., 2003). The sulfate profile and the lower part of the methane profile were very similar in P806GC and P824GC and also the rates did not differ sufficiently to provide an explanation why tailing occurred in one core but not in the other. Thus, methane tailing cannot simply be explained by low rates of AOM in the major AOM zone. Apparently the consumption of methane at concentrations $<0.5 \mathrm{mM}$, at the upper end of the 
AOM zone around $\sim 160 \mathrm{~cm}$ depth, was much less efficient in P806GC compared to P824GC and resulted in methane tailing. The reason why AOM is inefficient at $<0.5 \mathrm{mM} \mathrm{CH}_{4}$ at P806GC and P771GC, whereas such concentrations are further depleted by methanotrophic archaea at P824G, is not known.

The key difference between P824GC and the cores P771GC and P806GC is the location of the SMTZ relative to the Unit IIb-IIa transition from brackish clay to sapropel. In P771GC and P806GC it occurred deep within Unit IIb, whereas the SMTZ in core P824GC occurred close to the sapropel. Moreover, tailing of methane in all cores ended exactly at the bottom of the sapropel layer. This was also the case in cores studied by Jørgensen et al. (2004). It might be characteristic that the location of the SMTZ in the limnic layers of the sediment is the reason for the low rates and the sluggish turnover of methane. Tailing of methane has also been observed at other sites where buried limnic sediments are overlain by marine deposits, e.g. in the Baltic Sea, (Iversen and Jørgensen, 1985; Piker et al., 1998; Treude et al., 2005b) or in Saanich Inlet (Devol and Anderson, 1984), although the tailing is not as pronounced there as in the Black Sea. At those locations AOM takes place in the marine deposits and the sediments of the Black Sea are thus unusual because the entire SMTZ is located in the brackish and limnic sediment layers.

The significance of the UnitIIb-IIa transition is also evident in the SRR profile of core P824GC, the only core to show sulfate reduction activity based on organic matter degradation in the top $110 \mathrm{~cm}$. The drop in organic matterrelated SRR coincided with the shift from sapropel to grey clay (Fig. 2). The core was sampled in an area of mass wasting where slides from the central divide of the Dnjepr canyon have been identified (Naudts et al., 2006), and the thickness of the marine deposits at this site might be an indication that some of the sediment originated from such a submarine slide. The apparent absence of sulfate reduction based on sediment organic matter at the top of cores P771GC and P806GC is probably due to the loss of surface sediment during gravity coring since previous investigations of SRR in the Black Sea have reported high sulfate reduction rates confined to the top $\sim 10 \mathrm{~cm}$ of sediment (Albert et al., 1995; Dando and Niven, 1998; Weber et al., 2001). In core P806GC, this surface SRR may also have been low because the sediment was physically eroded on the flanks of the ridge where the core was collected. This suggestion is supported by a very thin accumulation of marine deposit on top of the sediment at this site.

It is noticeable that SRR took place throughout the marine deposit of P824GC, but not, or only with low rates, in the brackish and limnic sediment. In the limnic period during the last glaciation, the influx of organic matter from rivers was low and the limnic sediments are today very low in organic material whereas the marine deposits are organic rich. With the increase in salinity in the Black Sea some 9800 years ago, sulfate became available in the formerly limnic sediments where sulfate reduction rates are today strongly limited by the low content and reactivity of organic matter.

The burial rate and the degradation rate constant of organic matter deposited during the late Pleistocene to Holocene periods thus control the amount and depth distribution of organic substrate available today for sulfate reduction or methanogenesis. In the absence of bioirrigation under the modern anoxia of the Black Sea, the depth in the sediment at which sulfate becomes depleted appears not to be controlled by surface activity but rather by the methane flux which determines the methane-dependent sulfate reduction in the SMTZ (Jørgensen et al., 2004). The upwards diffusive flux of methane is, in turn, a result of the burial of degradable organic matter in the geological past and, although methanogenesis may take place in low-organic deposits, these have a great depth extension and thereby a significant accumulated methane production

The phylogenetic diversity of sulfate reducing bacteria in the limnic sediment layers could not be distinguished from the diversity in the marine deposits (Leloup et al., 2006), and also the relative abundance of SRB was comparable to other diffusive systems with a more efficient AOM zone (Parkes et al., 2007). Although very different kinds of organisms are included in the total cell counts, there is no indication that the low rates are based on a lack of the organisms mediating the processes (Leloup et al., 2006).

\subsection{Sulfate dynamics and $\mathrm{H}_{2} \mathrm{~S}$}

In core P771GC sulfate was apparently not depleted entirely at depth, but the influence of the methane related sulfate reduction created a linear sulfate profile in the upper part of the core. Compared to the SRR and AOM rates modeled by Jørgensen et al. (2001) at the neighbouring stations, the subsurface tracer determined rates were almost two orders of magnitude higher, and probably overestimate the actual activity.

AOM mediated by sulfate reduction usually takes place at the bottom of the sulfate zone, but because sulfate was not depleted at the bottom of the core it might be possible that continuing low SRR facilitate AOM below $330 \mathrm{~cm}$ depth. We detected sulfate concentrations of up to $1 \mathrm{mM}$ below $330 \mathrm{~cm}$ but it is not yet clear to what extend this constitutes a pool available to sulfate reducing bacteria. Since the $\mathrm{H}_{2} \mathrm{~S}$ profile for P771GC demonstrates that sulfide was depleted at $300 \mathrm{~cm}$ depth we conclude that the sulfate was not an artifact due to rapid re-oxidation of pore water sulfide during processing of the sediment and pore water extraction. It is also unlikely that the sulfate diffused down from the main sulfate zone because the sulfate turnover time is less than 10 years in the SMTZ and there was no gradient that could drive diffusion below $330 \mathrm{~cm}$. Therefore, the presence of sulfate in these deep sediment layers would imply a deep sulfate source, possibly based on the re-oxidation of iron-sulfides to sulfate 
(Neretin et al., 2004), The observation of these authors, that $\mathrm{H}_{2} \mathrm{~S}$ is trapped by iron from the formerly limnic sediment layers, is consistent with the disappearance of $\mathrm{H}_{2} \mathrm{~S}$ at depth in all three cores of our study. The diffusion front of dissolved iron usually coincides with the depletion of $\mathrm{H}_{2} \mathrm{~S}$ and black bands in the sediment generally mark this sulfidization (Jørgensen et al., 2004). In core P824GC the concentration of dissolved iron started to increase only $60 \mathrm{~cm}$ below the depth where sulfide disappeared, and it is not known what causes this separation. The increase of reactive iron in the solid phase started below the depth of $\mathrm{H}_{2} \mathrm{~S}$ depletion indicating that $\mathrm{Fe}^{2+}$ is dissolved from iron sources below and diffuses upwards, where it precipitates presumably as FeS. The $\mathrm{FeS}$ is eventually transformed to pyrite and adds to the pyrite formed during the limnic, sulfate-limited stage $>9800 \mathrm{yr}$ ago (Jørgensen et al., 2004). Originally $\mathrm{Fe}^{2+}$ had probably been present in the entire limnic sediment, but as more sulfate became available with increasing salinity, it was trapped by sulfide production, and so the sulfidization front moved downwards after the Holocene/Pleistocene transition (Jørgensen et al., 2004; Neretin et al., 2004). This penetration of the sulfidization front was similar at all three sites, with sulfide depletion ca. $200 \mathrm{~cm}$ below the sapropel layer.

As a result of the sulfide sink in deeper sediment layers, the thermodynamic yield available for microorganisms that carry out sulfate reduction coupled to AOM is very favourable at this depth. That might favour the occurrence of these processes mainly at the bottom of the SMTZ, even though both methane and sulfate are present over a broad zone (Knab et al., 2008).

\subsection{Methanogenesis and stable isotopes}

The role of bicarbonate-based methanogenesis in the cores presented is not entirely clear. The presence of detectable sulfate in the entire $500 \mathrm{~cm}$ long gravity core P771GC might be an explanation why no bicarbonate methanogenesis was detectable in this core. Yet, the methane in the Black Sea has been reported to be of biogenic origin (Amouroux et al., 2002, Michaelis et al., 2002), which is consistent with the $\delta^{13} \mathrm{C}_{-} \mathrm{CH}_{4}$ values of $-100 \%$ o to $-80 \%$ o measured in our cores.

Biogenic methane formation typically yields $\delta^{13} \mathrm{C}_{-} \mathrm{CH}_{4}$ values of $-100 \%$ o to $-60 \%$ (Whiticar and Faber, 1986). A positive shift in $\delta^{13} \mathrm{C}$ towards less negative values in residual methane subjected to AOM (or aerobic methane oxidation) is commonly observed and results from the fractionation of carbon isotopes by methane-consuming microorganisms. A resulting ${ }^{13} \mathrm{C}$-enrichment of methane in the main AOM zone was observed in P771GC and P806GC, similar to other AOM sites (e.g. Whiticar and Faber, 1986; Alperin et al., 1988). In core P824GC, in contrast, $\delta^{13} \mathrm{C}_{-} \mathrm{CH}_{4}$ values became more negative at the top of the SMTZ. Seifert et al. (2006) suggested for AOM mats from the Black Sea that such a trend may result from methanogenesis rates exceeding those of AOM. However, in core P824GC it seems unlikely that bicarbonate-based methanogenesis rates at $160 \mathrm{~cm}$ depth are greater than AOM rates.

Although rates of methanogenesis are low in all three cores it appears that the greater content of organic matter in core P824GC and its proximity to the main zone of AOM activity results in greater recycling of $\delta^{13} \mathrm{C}$-depleted $\mathrm{CO}_{2}$ derived from methane oxidation. This effect has been previously described by Borowski et al. (1997) and can yield highly negatively $\delta^{13} \mathrm{C}_{-} \mathrm{CH}_{4}$ values (e.g., $<-100 \%$ ) as a result of the normal $\mathrm{C}$-isotope fractionation associated with bicarbonatebased methanogenesis ( $\sim 60$ to $70 \%$ ) being coupled with ${ }^{13} \mathrm{C}$-depleted $\mathrm{CO}_{2}$ produced from AOM. It remains unclear why recycling of AOM-derived $\mathrm{CO}_{2}$ is more prominent in some sediments than in others. Data from the three Black Sea gravity cores suggest that availability of electron donors from degradation of local sedimentary organic matter may be a prerequisite for extensive C-recycling in the vicinity of the AOM zone. Noteworthy is that $\delta^{13} \mathrm{C}$-DIC values are comparatively negative in cores P771GC and P824GC, but anomalous ${ }^{13} \mathrm{C}$-depletion of methane does not occur in core P771GC where the SMTZ lies entirely within the organicmatter-poor limnic sediments. In all three cores, maxima in DIC concentration coincide with the main SMTZ, thus diffusion of AOM-derived $\mathrm{CO}_{2}$ both above and below the main zone of AOM activity is possible. Yet, only in core P824GC does the ${ }^{13} \mathrm{C}$-poor DIC contribute to production of methane directly in the AOM zone, having highly negatively $\delta^{13} \mathrm{C}$ values.

A further distinction worth noting in the three cores is that methane-tailing exists only where recycling of AOMproduced $\mathrm{CO}_{2}$ does not appear to occur. In core P806GC the peak of the bicarbonate-based methanogenesis measured in the SMTZ was located above the AOM zone and is consistent with the enrichment of $\delta^{13} \mathrm{C}-\mathrm{CO}_{2}$ at $\sim 160 \mathrm{~cm}$ and the less negative $\delta^{13} \mathrm{C}_{-} \mathrm{CH}_{4}$ signal at this depth due to the enhanced production of ${ }^{12} \mathrm{C}-\mathrm{CH}_{4}$. But $\delta^{13} \mathrm{C}$ values are not nearly as negative as from core $\mathrm{P} 824 \mathrm{GC}$ indicating that a direct recycling of the produced ${ }^{12} \mathrm{C}-\mathrm{CO}_{2}$ does not occur in P806GC. Thus, bicarbonate methanogenesis above the methane oxidation zone might be discussed as the reason for methane tailing at site P806GC, but this would not be consistent with the data from P771GC, where tailing also occurred. It seems, however, possible that the efficiency of AOM may be linked to degradation of organic matter within the sedimentary matrix.

Acetate methanogenesis was found in all three cores, with highest rates just below the bottom of the sapropel layer, but the rates were far lower than the AOM rates, and much too low to account for significant methane production in the depth intervals studied. The absence of measurable rates of methanogenesis combined with stable isotope evidence for a biogenic origin of the methane suggests that the main methanogenic zone is located below the sampling depth of these cores and that rates of methanogenesis in the sediment 
are extremely low and difficult to detect with the method used. Due to the gradual decrease of degradability of buried organic matter with depth and age, methanogenesis rates should be lower than the overlying SRR, yet high enough to sustain the methane flux into the SMTZ. The methane flux results from the integrated methane production over a deep methanogenic zone, reaching far down into the sediment. As an example, a methanogenesis rate of $1 \mathrm{pmol} \mathrm{cm}^{-3} \mathrm{~d}^{-1}$ over a $20 \mathrm{~m}$ interval would be sufficient to maintain the observed methane flux of $19 \mu \mathrm{mol} \mathrm{m}^{-2} \mathrm{~d}^{-1}$ from P771GC. Integrated rates of measured AOM $\left(45 \mu \mathrm{mol} \mathrm{m}^{-2} \mathrm{~d}^{-1}\right)$ exceed the calculated methane flux and should therefore be sufficient to oxidize methane completely.

\section{Conclusions}

The incomplete oxidation of methane in the major AOM zone and resulting methane tailing is a common feature of diffusion dominated methane rich sediments of the western Black Sea. The sluggish oxidation seems to be related to the location of the SMTZ in the sediment with a brackish or limnic history. Tailing of methane was less pronounced in core P824GC, where the SMTZ was located close to the sapropel and where the limnic sediment was covered by a thick layer of marine deposits. In contrast to the typical increase in $\delta^{13} \mathrm{C}_{-}-\mathrm{CH}_{4}$ due to $\delta^{12} \mathrm{C} \mathrm{CH}_{4}$ utilization in the $\mathrm{AOM}$ zone the stable isotope composition became lighter in core P824GC suggesting that recycling of $\delta^{13} \mathrm{C}$-depleted $\mathrm{CO}_{2}$, derived from $\mathrm{AOM}$, occurred in this core in contrast to P771GC and P806GC. Such a methane cycling in the AOM zone might be based on higher levels of organic matter at the site of P824GC. In contrary, at the sites where the SMTZ is located in the originally limnic sediments it might be suggested that methanogenesis above the AOM zone could result in a tailing of the methane profile, which would be consistent with the data from P806GC but could not be confirmed at P771GC. The importance of the brackish-marine transition was further indicated by the disappearance of methane at this transition in all cores, as well as the restriction of heterotrophic SRR to the marine deposits in P824GC.

Acknowledgements. We thank the scientific shipboard party as well as captain and crew of Poseidon 317/2 for their help on board. Tina Treude and Imke Busse are thanked for assistance with rate measurements. The comments of Sabine Kasten and two anonymous reviewers were very helpful and highly appreciated. This work was supported by the Max-Planck Society Germany as part of the EU-project METROL, funded by the European Commission in the 5th framework programme (contract no. EVK3-CT-2002-00080).

Edited by: C. Slomp

\section{References}

Albert D. B., Taylor, C., and Martens, C. S.: Sulfate reduction rates and low molecular weight fatty acid concentrations in the water column and surficial sediments of the Black Sea, Deep-Sea Res. Pt. I, 42, 1239-1260, 1995.

Alperin M. J., Reeburgh, W. S., and Whiticar, M. J.: Carbon and hydrogen isotope fractionation resulting from anaerobic methane oxidation, Global Biogeochem. Cy., 2, 279-288, 1988.

Amouroux, D., Roberts, G., Rapsomanikis, S., and Andreae, M. O.: Biogenic gas $\left(\mathrm{CH}_{4}, \mathrm{~N}_{2} \mathrm{O}\right.$, DMS $)$ emissions to the atmosphere from near-shore and shelf waters of the northwestern Black Sea, Estuar. Coast. Shelf S., 54, 575-587, 2002.

Arthur, M. A. and Dean, W. E.: Organic-matter production and preservation and evolution of anoxia in the Holocene Black Sea, Paleoceanography, 13, 395-411, 1998.

Borowski W. S., Paull C. K., and Ussler W.: Carbon cycling within the upper methanogenic zone of continental rise sediments: An example from the methane-rich sediments overlying the Blake Ridge gas hydrate deposits, Mar. Chem., 57(3-4), 299-311, 1997.

Brumsack H. J.: Geochemistry of recent TOC-rich sediments from the Gulf of California and the Black Sea, Geochemische Rundschau, 78, 851-882, 1989.

Calvert, S. E., Karlin, R. E., Toolin, L. J., Donahue, D. J., Southon, J. R., and Vogel, J. S.: Low organic carbon accumulation rates in the Black Sea sediments, Nature, 350, 692-695, 1991.

Canfield, D. E.: Reactive iron in marine sediments, Geochim. Cosmochim. Ac., 53, 619-632, 1989.

Cline, J. D.: Spectrophotometric determination of hydrogen sulfide in natural waters, Limnol. Oceanogr., 14(3), 454-458, 1969.

Dando, P. R. and Niven, S. J.: Sulphate reduction rates in a methane seepage area of the Black Sea, in: Berichte aus dem Zentrum für Meeres- und Klimaforschung, edited by: Luth, U., Luth, C., and Thiel, H., Institut für Hydrobiologie und Fischereiwissenschaft, Universität Hamburg, Germany, 27-35, 1998.

Devol, A. H. and Anderson, J. J.: A model for coupled sulfate reduction and methane oxidation in the sediments of Saanich Inlet, Geochim. Cosmochim. Ac., 48, 993-1004, 1984.

Goulder, R.: Attached and free bacteria in an estuary with abundant suspended solids, J. Appl. Bacteriol., 43(3), 399-405, 1977.

Ferdelman, T. G., Fossing, H., Neumann, K., and Schulz, H. D.: Sulfate reduction in surface sediments of the southeast Atlantic continental margin between 15 \# 28'S and 27 \# 57'S (Angola and Namibia), Limnol. Oceanogr., 44(3), Part 1, 650-661, 1999.

Fossing H.: Sulfate reduction in shelf sediments in the upwelling region off central Peru, Cont. Shelf Res., 10(4), 355-367, 1990.

Hall, P. O. J. and Aller, R. C.: Rapid, small-volume flow-injection analysis for $\Sigma \mathrm{CO}_{2}$ and $\mathrm{NH}_{4}^{+}$in marine and freshwaters, Limnol. Oceanogr., 37, 1113-1118, 1992.

Hensen, C., Zabel, M., Pfeiffer, K., Schwenk, T., Kasten, S., Riedinger, N., Schulz, H. D., and Boetius, A.: Control of sulfate pore-water profiles by sedimentary events and the significance of anaerobic oxidation of methane for the burial of sulfur in marine sediments, Geochim. Cosmochim. Ac., 64(14), 2631-2647, 2003.

Iversen, N. and Jørgensen, B. B.: Anaerobic methane oxidation rates at the sulfate methane transition in marine sediments from Kattegat and Skagerrak (Denmark), Limnol. Oceanogr., 30(5), 944-955, 1985. 
Iversen, N. and Jørgensen, B. B.: Diffusion-coefficients of sulfate and methane in marine sediments - Influence of porosity, Geochim. Cosmochim. Ac., 57(3), 571-578, 1993.

Jørgensen, B. B.: Comparison of methods for the quantification of bacterial sulfate reduction in coastal marine sediments 1 . Measurement with radiotracer techniques, Geomicrobiol. J., 1(1), 11-27, 1978.

Jørgensen, B. B., Weber, A., and Zopfi, J.: Sulfate reduction and anaerobic methane oxidation in Black Sea sediments, Deep-Sea Res. I, 48(9), 2097-2120, 2001.

Jørgensen, B. B., Böttcher, M. E., Lüschen, H., Neretin, L. N., and Volkov, II.: Anaerobic methane oxidation and a deep $\mathrm{H}_{2} \mathrm{~S}$ sink generate isotopically heavy sulfides in Black Sea sediments, Geochim. Cosmochim. Ac., 68(9), 2095-2118, 2004.

Joye, S. B., Boetius, A., Orcutt, B. N., Montoya, J. P., Schulz, H. N., Erickson, M. J., and Lugo, S. K.: The anaerobic oxidation of methane and sulfate reduction in sediments from Gulf of Mexico cold seeps, Chem. Geol., 205(3-4), 219-238, 2004.

Kallmeyer, J., Ferdelman, T. G., Weber, A., Fossing, H., and Jørgensen, B. B.: A cold chromium distillation procedure for radiolabelled sulfide applied to sulfate reduction measurements, Limnol. Oceanogr.-Meteor., 2, 171-180, 2004.

Knab, N. J., Dale, A. D., Lettmann, K., Fossing, H., and Jørgensen, B. B.: Thermodynamic and kinetic control on anaerobic oxidation of methane in marine sediments. Geochim. Cosmochim. Ac, 72, 3746-3757, 2008.

Leloup, J., Loy, A., Knab, N. J., Borowski, C., Wagner, M., and Jørgensen, B. B.: Diversity and abundance of sulfatereducing microorganisms in the sulfate and methane zones of a marine sediment, Black Sea Environ. Microbiol., 131-142, doi:10.1111/j.1462-2920.2006.01122.x, 2006.

McAullife, C.: GC Determination of solutes by multiple phase equilibration, Chem. Technol., 1, 46-51, 1971.

Michaelis, W., Seifert, R., Nauhaus, K., Treude, T., Thiel, V., Blumenberg, M., Knittel, K., Gieseke, A., Peterknecht, K., Pape, T., Boetius, A., Amann, R., Jørgensen, B. B., Widdel, F., Peckmann, J. R., Pimenov, N. V., and Gulin, M. B.: Microbial reefs in the Black Sea fuelled by anaerobic oxidation of methane, Science, 297(5583), 1013-1015, 2002.

Naudts, L., Greinert, J., Artemov, Y., Staelens, P., Poort, J., Van Rensbergen, P., and De Batist, M.: Geological and morphological setting of 2778 methane seeps in the Dnepr paleo-delta, northwestern Black Sea, Mar. Geol., 227, 177-199, 2006.

Neretin, L. N., Böttcher, M. E., Jørgensen, B. B., Volkov, I., Lüschen, H., and Hilgenfeldt, K.: Pyritization processes and greigite formation in the advancing sulfidization front in the Upper Pleistocene sediments of the Black Sea, Geochim. Cosmochim. Ac., 68(9), 2081-2093, 2004.

Niemann, H., Elvert, M., Hovland, M., Orcutt, B., Judd, A. G., Suck, I., Gutt, J., Joye, S., Damm, E., and Finster, K.: Methane emission and consumption at a North Sea gas seep (Tommeliten area), Biogeosciences, 2, 335-351, 2005,

http://www.biogeosciences.net/2/335/2005/.

Niemann, H., Lösekann, T., de Beer, D., Elvert, M., Nadalig, T., Knittel, K., Amann, R., Sauter, E. J., Schlüter, M., Klages, M., Foucher, J. P., and Boetius, A.: Novel microbial communities of the Haakon Mosby mud volcano and their role as a methane sink, Nature, 443, 854-858, 2006.
Niewöhner, C., Hensen, C., Kasten, S., Zabel, M., and Schulz, H. D.: Deep sulfate reduction completely mediated by anaerobic methane oxidation in sediments of the upwelling area off Namibia, Geochim. Cosmochim. Ac., 62(3), 455-464, 1998.

Orcutt, B. N., Boetius, A., Lugo, S. K., MacDonald, I. R., Samarkin, V. A., and Joye, S. B.: Life at the edge of methane ice: Microbial cycling of carbon and sulfur in Gulf of Mexico gas hydrates, Chem. Geol., 205(3-4), 239-251, 2004.

Parkes, J., Banning, N., Brock, F., Webster, G., Fry,, J. C., Hornibrook, E., Pancost, R. D., Kelly, S., Knab, N. J., Weightman, A. J., and Cragg, B. A.: Biogeochemistry and biodiversity of methane cycling in subsurface marine sediments (Skagerrak, Denmark), Environ. Microbiol., 1146-1161, doi:10.1111/j.14622920.2006.01237.x., 2007.

Piker L., Schmaljohann R., and Imhoff J. F.: Dissimilatory sulfate reduction and methane production in Gotland Deep sediments (Baltic Sea) during a transition period from oxic to anoxic bottom water (1993-1996), Aquat. Microb. Ecol., 14, 183-193, 1998.

Popescu, I., Lericolais, G., Panin, N., Wong, H. K., and Droz, L.: Late Quaternary channel avulsions on the Danube deep-sea fan, Mar. Geol., 173, 25-37, 2001.

Reeburgh, W. S., Ward, B. B., Whalen, S. C., Sandbeck, K. A., Kilpatrick, K. A., and Kerkhof, L. J.: Black Sea methane geochemistry, Deep-Sea Res., 38, S1189-S1210, 1991.

Ross, D. A., Degens, E. T., and MacIlvaine, J.: Black Sea: Recent sedimentary history, Science, 170(3954), 163-165, 1970.

Schulz, H. D.: Quantification of early diagenesis: Dissolved constituents in marine pore water, in: Marine Geochemistry, edited by: Schulz, H. D. and Zabel, M., Springer Verlag, Berlin, Germany, 85-128, 2000.

Seifert, R., Nauhaus, K., Blumenberg, M., Krüger, M., and Michaelis, W.: Methane dynamics in a microbial community of the Black Sea traced by stable isotopes in vitro, Org. Geochem., 37(10), 1411-1419, 2006.

Stookey, L. L.: Ferrozine - A new spectrophotometric reagent for iron, Anal. Chem., 42, 779-781, 1970.

Thamdrup, B., Rossello-Mora, R. A., and Amann, R.: Microbial manganese and sulfate reduction in Black Sea sediments, Appl. Environ. Microb., 66(7), 2888-2897, 2000.

Treude, T., Boetius, A., Knittel, K., Wallmann, K., and Jørgensen, B. B.: Anaerobic oxidation of methane above gas hydrates at Hydrate Ridge, NE Pacific Ocean, Mar. Ecol. Prog. Ser., 264, 1-14, 2003.

Treude, T., Knittel, K., Blumenberg, M., Seifert, R., and Boetius, A.: Subsurface microbial methanotrophic mats in the Black Sea, Appl. Environ. Microb., 71(10), 6375-6378, 2005a.

Treude, T., Krüger, M., Boetius, A., and Jørgensen, B. B.: Environmental control on anaerobic oxidation of methane in the gassy sediments of Eckernförde Bay (German Baltic), Limnol. Oceanogr., 50(6), 1771-1786, 2005b.

Weber, A., Riess, W., Wenzhoefer, F., and Jørgensen, B. B.: Sulfate reduction in Black Sea sediments: In situ and laboratory radiotracer measurements from the shelf to $2000 \mathrm{~m}$ depth, Deep-Sea Res. Pt. I, 48(9), 2073-2096, 2001.

Whiticar, M. J. and Faber, E.: Methane oxidation in sediment and water column environments - Isotope evidence, Org. Geochem., 10, 759-768, 1986. 